\title{
Prostate Soft Tissue Neoplasm
}

National Cancer Institute

\section{Source}

National Cancer Institute. Prostate Soft Tissue Neoplasm. NCI Thesaurus. Code C161045.

A mesenchymal neoplasm that arises from the prostate gland. 